\title{
Person-Situation Transactions Across the Lifespan
}

\author{
Katherine S. Corker \\ Grand Valley State University
}

M. Brent Donnellan

Texas A\&M University

This is the version as of January 23, 2017.

Minor alterations were made in the copy editing stage.

Chapter appears in Oxford Handbook of Psychological Situations (2017).

J. F. Rauthmann, R. A. Sherman, \& D. C. Funder (Eds.)

DOI of the published chapter: 10.1093/oxfordhb/9780190263348.013.26 


\begin{abstract}
Research on situations has been reinvigorated within social and personality psychology. We argue that a developmental perspective on situations can further enrich the understanding of person-situation transactions and generate interesting predictions for future empirical tests. Our approach is grounded in life course theory (Elder \& Shanahan, 2006), an interactionist approach that considers person-situation dynamics as critical to understanding individual lives. In this chapter, we describe our overarching perspective and review principles of personality development before turning to an explicit consideration of how situational characteristics (the Situational Eight DIAMONDS; Rauthmann et al., 2014) may change with age. We then outline how a developmental tasks perspective and socioemotional selectivity theory can be integrated with the DIAMONDS characteristics. We conclude by describing different kinds of personsituation transactions that promote consistency and change in psychological characteristics across the lifespan and suggest a few future directions for research.
\end{abstract}

Keywords: Lifespan development, person-situation interactions, life tasks, personality traits, situational characteristics, stability and change 


\section{Person-Situation Transactions Across the Lifespan}

A long tradition of theorizing in developmental psychology (e.g., Caspi, Elder, \& Bem, 1989; Magnusson \& Stattin, 2006; Scarr \& McCartney, 1983) and behavior genetic research (Briley \& Tucker-Drob, 2014; Plomin, DeFries, \& Loehlin, 1977; Rowe, 1987) emphasizes transactions between individuals and their environments. These accounts share the idea that dispositional and situational factors are inexorably linked to behavior through transactive processes such as when individuals evoke situational responses because of their traits and when individuals select certain situations because of their personality attributes. For instance, children can evoke particular parental reactions and thereby influence the parenting they receive from caregivers (e.g., Bell \& Chapman, 1986), and youth prone to alcohol use may select into groups of likeminded peers thereby coupling social selection and social influence processes (e.g., Scalco, Trucco, Coffman, \& Colder, 2015). Indeed, examples of evocative person-situation transactions and selection effects are prevalent in developmental science.

An interactionist perspective is also becoming more prominent in social/personality psychology because of the resolution of the person-situation debate (Buss, 1987; Ickes, Snyder, \& Garcia, 1997; Kenrick \& Funder, 1988; Synder, 1983) and the increased attention in the literature to the psychological dimensions of situations (e.g., Rauthmann, Sherman, \& Funder, 2014). Given these converging intellectual developments, we propose that a developmental perspective can supplement recent efforts to revitalize the concept of the situation in social/psychology. A developmental perspective affirms the importance of person-situation transactions played out over time (e.g., Shiner, 2009) and draws attention to how age intersects with the matrix of constraints and opportunities afforded by different social contexts to shape 
person-situation transactions. The goal of this chapter is to describe our perspective, and we begin by outlining a general meta-theoretical approach to these issues.

\section{Meta-Theoretical Assumptions from Life Course Theory}

Life course theory is an explicitly interactionist approach that views "the interplay of social context and the organisms as the formative process, making people who they are" (Elder \& Shanahan, 2006, p. 670). These ideas guide our thinking about how person-situation transaction from a developmental perspectives. As we see it, four key principles are relevant to the aims of our chapter. These ideas are distilled from existing theoretical writings about life course theory and life span theory in developmental psychology (e.g., Baltes Staudinger, \& Lindenberger, 1999) and our own perspectives on these issues.

1. Human development is a lifelong process characterized by dynamic patterns of growth and decline, gains and losses, and selection and compensation (e.g., see also Baltes, Lindenberger, \& Staudinger, 2006). These dynamics continue from birth until death and can create both stability and change in individual characteristics.

2. Developmental trajectories (i.e., the courses of individual development) are shaped by the opportunities and constraints provided by the broader social cultural context (e.g., SES, culture, point in history). These opportunities and constraints create a matrix of immediate situations that transact with individual dispositions to produce thoughts, feelings, desires, and behaviors in the moment.

3. Relationships with others are often the most important elements of situations for understanding developmental processes (Reis, Collings, \& Berscheid, 2000), and they are often a significant conduit of broader contextual influences. Indeed, human lives are embedded in relationships (e.g., parent-child, peers, romantic partners, teacher-learner, 
and supervisor-subordinate relationships in the workplace) throughout the life span. Moreover, issues of achievement, aggression, affiliation, attachment, closeness, dominance, and social status are intimately tied to interpersonal relationships (see e.g., Mund, Finn, Hagemeyer, \& Neyer, 2016). Even when individuals are engaged in seemingly solitary activities like completing a work report or exercising, it is often possible to frame the activities in relational terms. A supervisor will typically read the report, and exercise can have interpersonal consequences in terms of increased longevity and attractiveness.

4. Major life transitions such as attending formal schooling, experiencing puberty, and starting a career are important times to examine person-situation transactions. Such transitions often entail alterations in situational characteristics and can either limit or expand an individual's ability to modify situational features (e.g. Buss, 1987) or to nichepick situations consistent with their dispositions (Scarr \& McCartney, 1983). Life transitions that launch individuals into situations that have a diffuse incentive structure and lack clear norms for behavior tend to accentuate existing dispositions and contribute to personality continuity (e.g., Caspi \& Moffitt, 1993). Life transitions that launch individuals into situations that have a clear press and incentive structure for producing particular patterns of thinking, feeling, and behaving may contribute to behavioral change. Repeated exposure to such contextual factors may alter dispositions in the long term (e.g., Wrzus \& Roberts, in press).

These four "big ideas" influence how we conceptualize person-situation transactions across the lifespan. In the next sections, we (1) summarize recent work concerning personality 
development across the lifespan to ground the person side of our discussion; (2) consider recent work about the psychology of situations that helps identify the critical attributes of situations that are developmentally relevant; and (3) outline two different perspectives on the central themes and motivations that characterize different times in the life span. These themes and motivations influence how individuals construe and approach the situations of everyday life. We conclude with a discussion of specific types of person-situation transactions and outline future directions.

\section{Considering Personality from a Developmental Perspective}

The topic of personality development is enjoying a renaissance as scholars from disciplines such as economics, education, developmental psychology, quantitative psychology, personality assessment, and social/personality psychology have taken renewed interest in three inter-related topics: the assessment of individual differences across the lifespan, how individual differences develop across the lifespan, and factors that are associated with changes in personality constructs. These three areas reflect advances in measurement, the description of personality development, and the testing of hypotheses about personality continuity and change. McAdams (2015) provides an interesting book length treatment of the field, and multiple handbook chapters and annual review chapters are devoted to the topic (e.g., Caspi, Roberts, \& Shiner, 2005; McAdams \& Olson, 2010; Roberts, Donnellan, \& Hill, 2012; Roberts, Wood, \& Caspi, 2008). Below we highlight four themes in the contemporary literature that are important to think about when considering person-situation transactions across the life span.

There are multiple levels of individuality. A long tradition in personality psychology works to identify taxonomies of traits through the application of factor-analytic methods to descriptors found in natural language and to the scales and items that constitute omnibus inventories designed to measure individuality for use in applied settings such as personnel 
selection and clinical diagnosis. This work has identified a smaller set of basic personality dispositions such as those found in the Five-Factor Model (e.g. Digman, 1990) or the HEXACO set of domains (e.g., Ashton \& Lee, 2007). At the same time, work on constructs such as attachment styles, goals, motives, and identity constructs have generated productive but largely independent literatures. An important advance in the last decade or so of scholarship in personality psychology are the attempts to integrate these disparate traditions to provide overarching models of individuality and personality (e.g., Mayer, 2005; McAdams \& Pals, 2006; McCrae \& Costa, 2008; Roberts \& Wood, 2006).

At this point there is no consensus about which particular integrative approach is best suited for the task of organizing the various ways people can differ from one another. Nonetheless, commonalities exist. One general idea is the existence of hierarchies of individual differences ranging from dispositions to aspects of identity and life narratives. The dispositional level reflects constructs that seem to be present early in the life span, are more or less evident in people from different cultures, and are theoretically rooted in neurobiological systems governing emotional experience and self-regulation. These are the constructs often identified in the factoranalytic tradition of personality psychology. The narrative level of these hierarchies contains constructs that are thought to be strongly conditioned on lived experiences, self-reflective capabilities, and cultural factors that provide a menu for how individuals define their own lives and their place in society. In between these two classes are constructs like goals and motives that are more contextualized than dispositions but not as uniquely self-reflective or idiosyncratic as life narratives and aspects of identity (see e.g., Corker, Donnellan, \& Bowles, 2013).

Hierarchies of personality constructs provide a starting point for integrating different streams of personality research and for drawing attention to the different kinds of constructs that 
need to be approached from a developmental perspective. In some hierarchical models, there is also an explicit developmental perspective such that dispositions emerge early in the life span and therefore partially shape the kinds of goals individuals pursue in specific contexts and ultimately influence the kinds of stories individuals tell about their lives (e.g., McAdams \& Pals, 2006; Roberts \& Wood, 2006). At the same time, there is also the recognition that each element in the hierarchy cannot be simply reduced to basic dispositions. Understanding a whole person requires more than just knowledge about how that person scores on a set of basic trait domains (see e.g., McAdams, 2001). Likewise, a thorough understanding of person-situation transactions requires that researchers identify what kind of individual difference constructs are involved in the transaction.

Individuality is present early in the lifespan. Parents of multiple children, pediatricians, and preschool teachers can all attest to an important insight about human nature - individuality is present early in the life span. Indeed, this insight has been recognized in both medicine and psychology at least as far back as classic research on temperament by Chess and Thomas (e.g., 1977). Contemporary research in developmental psychology is building on these early insights in efforts to identify the basic domains of temperament and to study the consequences of individual differences in temperament and childhood personality for developmental outcomes such as achievement, parent-child relationships, and psychological health and well-being (e.g., Rothbart, 2011; Shiner, Buss, McClowry, Putnman, Saudino, \& Zentner, 2012; Soto \& Tackett, 2015).

To be sure, researchers have increasingly recognized that dimensions of temperament in children and trait dispositions studied in the adult personality literature have much in common and might even be isomorphic (e.g., Caspi et al. 2005; Clark \& Watson, 2008). Regardless of the precise integration of the temperament and adult trait literatures, a key implication of this theme 
is that person-situation transactions occur across the lifespan and are likely to be present very early in development. Indeed, it is quite likely that the characteristics of even newborns and infants help to shape their environmental experiences, challenging a blank slate model of human nature (Pinker, 2003).

Personality development is characterized by non-negligible coherence, increasing consistency, and increasing maturity from adolescence to adulthood. Treatments of personality development devote considerable attention to the different ways that personality stability and personality change can be defined and investigated with various statistical approaches and summary indices (e.g., retest correlations versus random effects in growth curve models). The conclusions drawn about personality development are multifaceted because multiple types of stability and change exist. Nonetheless, this work has produced several generalizations that are well supported by multiple lines of evidence.

One type of personality stability defined in the literature is called heterotypic continuity (e.g., Caspi \& Bem, 1990). This concept refers to the fact that the same underlying disposition can have different expressions at different points in the lifespan. Shyness and aggressiveness are good examples because the behavioral referents of these tendencies change with age. The ways that toddlers express aggression are different from the ways that adults express aggression. This fact must be taken into account when addressing issues of personality consistency. If researchers were to naively define aggression as the number of times an individual bites and steals toys from peers, there would be little evidence of consistency from early childhood to adulthood. However, if a more psychologically sophisticated researcher measured aggression in appropriate ways in childhood versus in adulthood in a longitudinal study, there might be evidence that the aggressive tendencies are at least somewhat stable across the life span. 
Findings from large-scale and long-term longitudinal studies show that personality attributes such as aggressiveness, self-control, and shyness show coherence from childhood to adulthood (e.g., Caspi, Elder, \& Bem, 1998; Nave, Sherman, Funder, Hampson, \& Goldberg, 2010; Moffitt et al., 2011). One such finding was reported by Caspi, Moffit, Newman, and Silva (1996) using data from a long-term study of a birth cohort in Dunedin, New Zealand. These researchers found that children rated by observers at age 3 as being impulsive and restless were more likely to have psychiatric problems at age 21 related to alcoholism and antisocial personality disorder.

Interpreting the size of long-term associations between early emerging individual differences and later personality attributes and adjustment outcomes can be contentious (e.g., Roberts, Kuncel, Shiner, Caspi, \& Goldberg, 2007). It is one likely to generate debate, and we believe the length of time and the importance of the outcome variable are important factors in interpreting the size of any developmental correlation. Gignac and Szodori (2016) noted the existence of common benchmarks such as small, medium, and large for correlations around .10, .30 , and .50 , respectively. However, they surveyed the individual differences literature and suggested that coefficients of $.11, .19$, and .29 represent the $25^{\text {th }}, 50^{\text {th }}$, and $75^{\text {th }}$ percentiles of the observed distribution of 708 meta-analytically estimated correlations. These values might serve as more reasonable rules of thumb for small, average, and large effects than older benchmarks.

Indeed, we suspect that many long-term correlations from childhood attributes to later assessments and outcomes are somewhere between .10 and .30 and thus would not likely be considered large in an objective sense. This means that early emerging behavioral tendencies are far from immutable, and prediction from childhood attributes to adult outcomes is far from perfect. Nonetheless, early individual differences do foreshadow adult outcomes in predictable 
ways, demonstrating personality coherence across the life span Understanding this coherence likely involves person-situation transactions.

A second type of personality stability or change refers to the amount of relative or rankorder consistency in individual differences across meaningful intervals of time. This is often called the study of differential stability. The basic question, for example, is whether highly talkative people at age 20 are also highly talkative at age 40 . The simplest approach to the study of differential stability is to use a longitudinal design and administer the same personality trait measure at both time points to compute a correlation coefficient for the scores. A large correlation indicates that rank-ordering was more or less preserved, whereas a near zero correlation indicates there is no preservation of rank-ordering over time. Sizeable negative correlations are not expected in such studies.

As it stands, personality researchers have conducted hundreds of these kinds of studies, and this has permitted a number of meta-analyses on these literatures (e.g., Ferguson, 2010; Roberts \& DelVecchio, 2000). These meta-analyses converge in providing a portrait of differential stability involving three conclusions. The first is that personality traits are consistent over appreciable intervals as retest coefficients are usually at least moderate in magnitude (a conclusion consistent with the conclusion of personality coherence noted above; see also Anusic \& Schimmack, 2016). It seems as if only measures of IQ and cognitive ability have higher retest correlations than personality attributes (e.g., Conley, 1984; Olweus, 1979). The second is that these retest correlations are never perfect, suggesting that changes in rank-ordering are possible. In other words, personality is never completely fixed or set like plaster (contrary to an infamous quote from William James). There are debates about how much measurement error is a factor in this attenuation (Ferguson, 2010), but meta-analytic correlations are still below unity, and 
correlations get weaker as the length of the retest interval increases (e.g., Fraley \& Roberts, 2005; Anusic \& Schimmack, 2016). The third and perhaps most interesting finding is that retest correlations get stronger with age but seem to reach a zenith between the ages of 50 and 70 and may even decline thereafter.

The pattern of the increasing consistency or differential stability of individual differences with age based on a consideration of test-retest correlations has been cast as the cumulative continuity principle of personality development (Caspi et al., 2005). Individual differences show more consistency with age presumably because the consequences of person-situation transactions accumulate over time. For example, youth with aggressive tendencies might evoke aggressive responses in others. These kinds of cycles may play out repeatedly across development to strengthen the initial tendency toward aggression. It is also the case that individuals have increasing ability to select environments during young adulthood and that environmental stability characterizes much of adulthood (see e.g., Kandler, 2012). Environmental stability would also promote the stability of reactions to situations. Thus, the cumulative continuity principle is often explicitly explained by reference to person-situation transactions.

The third type of personality stability (or change) is known as mean-level stability and refers to the absolute level of an attribute over time. The basic question, for example, is whether levels of self-control increase, decrease, or stay the same from adolescence to adulthood. This question can be addressed with either cross-sectional or longitudinal analyses but there is a preference in the literature for longitudinal studies as age differences are not confounded by birth-cohort differences (albeit researchers are limited to making generalizations about agerelated changes in absolute levels for typically one or a few select birth cohorts).

As was the case for the literature on differential stability, a number of longitudinal studies 
were available for a meta-analysis (Roberts, Walton, \& Viechtbauer, 2006). The existing metaanalyses and large-scale cross-sectional studies (e.g., Ashton \& Lee, 2016; Lucas \& Donnellan, 2011; Soto, John, Gosling, \& Potter, 2011) have produced several consistent results. The first is that average levels of traits are different across the life span suggesting that absolute levels of personality traits can change, even past age 30 (see James, 1890). The second is that young adulthood seems to be an active time for average changes. This is relevant for considering person-situation transactions because young adulthood is an active time in the life span for migration and demographic changes with respect to marriage, entering the workforce, divorce, and remarriage (Rindfuss, 1991). These changes suggest that situations might also be shifting during the young adult period.

One of the last notable findings from considering mean-level changes in personality traits is that the general direction of changes seems to be desirable in terms of increases in attributes such as conscientiousness, emotional stability, honesty-humility, and self-control that are relevant to successful role fulfillment. This general trend is known as the maturity principle of personality development (e.g., Caspi et al., 2005) given that individuals, on average, seem to increase in traits correlated with successful performance of roles and responsibilities in the major domains of life. Certain patterns of behaviors bring about positive outcomes during adulthood and thus particular tendencies might be reinforced during this period. The maturity generalization might be explained, in part, by person-situation transactions.

Processes are critical to understanding personality development. Researchers who study personality development consistently emphasize the importance of person-situation transactions for producing at least some of the patterns of coherence, increasing consistency, and changes toward maturity documented in the literature (e.g., Caspi \& Bem, 1990; Caspi \& Roberts, 2001; 
Caspi \& Shiner, 2006; Roberts, 2006; Roberts \& Pomerantz, 2004; Roberts et al. 2008; Roberts et al., 2012). A number of processes have been described and different sets of processes are thought to produce personality stability versus change (see Wrzus \& Roberts, in press, for a summary). For example, consistency promoting processes occur when individuals select into particular situations because of their pre-existing personality attributes (situational selection) or evoke predictable responses from others because of their personality attributes (situational evocation). Mechanisms that promote change involve situations with clear contingencies for specific patterns of thinking, feeling, and behaving (i.e., clear rewards and punishments) and those situations that limit an individual's ability to niche-pick and manipulate features of that situation. Unfortunately, many of these mechanisms have been difficult to systematically evaluate because the science of situations has been relatively impoverished. Accordingly, we now turn to a consideration of situations from a developmental perspective, and we return to a more detailed consideration of processes that promote consistency and change in the penultimate section of the chapter.

\section{Considering Situations from a Developmental Perspective}

There has been a long history in psychology regarding the importance of "the situation," “cultural context," and "the environment" in affecting behavior (Bowers, 1973; Cooper \& Withey, 2009; Epstein \& O’Brien, 1985; Kenrick \& Funder, 1988; Reis, 2008). The breadth of perspectives on these seemingly foundational variables has been sizable, and at least historically, there has been little in the way of a comprehensive framework to conceptualize situations or contexts from a psychological perspective. Situations have been viewed as qualitatively distinct classes (e.g., work vs. social situations), and when attempts have been made to quantify situational features, researchers have used a dizzying array of attributes such as the presence of 
particular physical cues (e.g., number of other people), occurrence of certain activities (e.g., doing chores), behavioral affordance (e.g., allowing expression of certain traits), and many more (Rauthmann, Sherman, \& Funder, 2014).

The perplexing status of the situation in psychological science is a problem for researchers interested in studying person-situation transactions across the lifespan. Roberts and Pomerantz (2004) offered this lamentation: "Unfortunately, the assessment of environments has not been as thorough or systematic as that of psychological attributes, so we do not have the opportunity to catalogue all forms of consistency and change for even a subset of situations or environments" (p. 406). It seems clear that exposure to and the prevalence of different situations must vary over the course of development, but without a meaningful model of situations, researchers have been limited in their ability to study these changes with precision. On this topic, Hans Eysenck wrote, "In any science, taxonomy precedes causal analysis; we must analyze and classify the entities in our field of study before we can frame meaningful theories concerning their behavior" (Eysenck, 1991, p. 774). It is not a stretch to argue that contemporary research in personality psychology is making progress, in part, because work on the taxonomic structure of traits and other work that has clarified the basic units of analysis ranging from dispositions to life stories (e.g., McAdams \& Pals, 2006). Luckily for researchers interested in the study of situations a basic situational taxonomy is beginning to take shape.

The DIAMONDS model (Rauthmann et al., 2014; Rauthmann et al., 2015) identifies eight continuous dimensions that capture the most psychologically relevant features of situations: Duty, Intellect, Adversity, Mating, pOsitivity, Negativity, Deception, and Sociality. These dimensions allow researchers to quantify the psychologically-relevant characteristics of situations in multidimensional space. This approach obviates the need for the potentially 
artificial exercise of reducing situations to a limited set of classes. Much like how trait taxonomies provide a common language for discussing important dispositions, the DIAMONDS model provides a common vocabulary to the study of situations. Brief descriptions of the DIAMONDS dimensions appear in Table 1.

The developmental implications of the DIAMONDS model have not yet been fully articulated, but we propose a starting point in Table 1. For example, developmental changes in situational characteristics are likely to be related to the Duty dimension. Preschool children are often in situations with fewer demands on their behavior compared elementary school students. More opportunities for free play exist in preschool, whereas recess is more limited later in primary school. Young adults typically encounter fewer situations involving work and responsibilities than middle aged adults who are full-time employees and caregivers to children and aging parents. Retired individuals have fewer work-related responsibilities than employed younger adults. Thus, a somewhat inverted-U shaped pattern for Duty over the life span seems plausible.

Only a handful of studies have begun to collect data concerning the developmental unfolding of DIAMONDS. A recent paper investigated age related changes in DIAMONDS dimensions over the lifespan (Brown \& Rauthmann, 2016). The researchers made use of two nationally representative samples from the United States and one nationally representative German sample, each of which contained studies of daily time use. Participants' daily activities (e.g., eating a meal, driving to work, caring for children) were coded according to their DIAMONDS characteristics. The typical levels of these characteristics were then evaluated against participants' ages, which spanned 15-85 in the US samples and 15-95 in the German sample. 
The results showed many instances of agreement between the different national contexts and revealed several interesting developmental patterns. Returning to the example of Duty, the dimension concerned with fulfilling obligations (e.g., work, childcare), results showed an increase in salience of this dimension from early adulthood into midlife, a subsequent decrease from midlife to old age, and some evidence of a final increase from old age to the oldest individuals in the samples (i.e., approximately 75 years old and up). This pattern held across all three independent samples. These situational results had some correspondence with changes in normative levels of personality traits across the life span. Conscientiousness seems to be the most relevant trait when considering the Duty dimension of DIAMONDS, and this trait domain has been shown to increase from young adulthood through midlife and subsequently decrease from midlife to older age (Donnellan \& Lucas, 2008; Lucas \& Donnellan, 2011). This hints at an interesting parallel between the situational characteristics that individuals experience and the traits they express. However, it is important to note that the Negativity dimension showed a similar pattern to Duty but such a pattern was not closely mapped to changes observed previously in Neuroticism (e.g., Lucas \& Donnellan, 2008), the trait domain with perhaps the closest ties to this situational characteristic. One possibility is that work is a stressful context and thus it produces negativity while also providing a context for the development of conscientiousness-related attributes. This underscores the reality that the correspondence between contexts and personality attributes is multifaceted.

To obtain a full understanding of how situations develop over the lifespan, researchers need longitudinal data. Such data would allow researchers to investigate rank-order stability and mean-level changes. In so doing, researchers will be able to bring a truly developmental perspective to bear on the study of situations. As it stands, the best longitudinal evidence for 
stability and change in DIAMONDS characteristics comes from a short-term diary study (Sherman, Rauthmann, Brown, Serfass, \& Jones, 2015). Those researchers assessed momentary thoughts, feelings, and behavior as well as situational characteristics as measured by the DIAMONDS dimensions, with respondents completing up to eight assessments per day for seven consecutive days. The results replicated previously observed between-person differences in thoughts, feelings, and behaviors with researchers finding that $36 \%$ of the variability was attributable to between person individual differences. However, the research team also found that there was substantial between person variability in situational characteristics, with intra-class correlations ranging from $17 \%-36 \%(M=26 \%)$. This finding supports a basic assumption of personality psychologists: the situations that people experience are not random, but are often selected (e.g., chosen or avoided) and manipulated to better suit an individual because of their personality traits (Roberts, 2006; Donnellan, Hill, \& Roberts, 2015).

Longitudinal studies of persons and situations in tandem can also allow researchers to observe person-situation transactions in real-time. Personality traits can be used to predict situational characteristics (i.e., situational selection), and situational characteristics can be used to predict personality states (i.e., situational construal). Sherman et al. (2015) modeled both of these effects using a six-factor model of personality (the HEXACO; e.g., Lee \& Ashton, in press) and conceptualizing personality states as temporary thoughts, feelings, and behaviors. Results showed support for bidirectional linkages between the person and their situation. For instance, trait Agreeableness and Honesty-Humility predicted less situational Deception, and trait Negative Emotionality predicted more situational Negativity. Moreover, situational Duty predicted state Conscientiousness, situational Intellect predicted state Openness to Experience, and situational Adversity predicted state Emotionality. In short, personality traits had predictable 
associations with situational characteristics, and situational characteristics had predictable associations with trait-relevant behaviors, again demonstrating the transactional relations between persons and situations.

In sum, the emergence of a working taxonomy of situational characteristics holds great promise for understanding person-situation transactions across the life span because researchers can draw on a common vocabulary. This common language provides developmentally-oriented researchers an ability to make specific hypotheses about changes in salient dimensions across the lifespan. Nonetheless, there remains much to learn about the development of situational characteristics, and we anticipate that this will be an active area of research going forward. We now turn to thinking about the major life tasks that characterize different periods of the lifespan and attempt to link these tasks with the dimensions identified in the DIAMONDS scheme. We then consider how Socioemotional Selectivity Theory can also offer a complementary perspective for positing connections between developmental processes and features of the situation.

\section{Developmental Tasks Across the Life Span}

One of Erik Erikson's central observations was that different themes characterize psychological development from infancy until the end of life (e.g. Erikson, 1950). Put differently, many of the motivations and goals that individuals pursue change in normative ways across development. This insight about human lives has implications for how individuals construe different situations and for the proximate and longer-term goals that individuals pursue in different situations.

Although Erikson's ideas are present in lifespan approaches to development, few contemporary scholars exclusively draw on Erikson's original eight stages or upon the fairly 
canonical psychoanalytic foundations of his work. Instead, more recent theorizing uses the concept of developmental tasks or the "age-graded normative tasks based on societal expectations about the developmental milestones that should be reached in specific life phases" (Hutteman, Hennecke, Orth, Reitz, \& Specht, 2014, p. 267). Many of these developmental tasks have parallels with the DIAMONDS framework and recognizing these connections can help researchers develop hypotheses about the situational dimensions that might be more or less relevant at different times in the lifespan.

Hutteman et al. (2014) proposed five theoretically universal domains for life tasks: romantic relationships, family life, job life, social life, and physical changes. For the purpose of this chapter, we will not consider physical changes in detail as this domain is less clearly tied to specific situations compared to the other four domains - though we note that physical changes are likely relevant to DIAMONDS dimensions like Mating and Intellect given well-documented age-related changes in both reproductive capabilities and cognitive functioning (e.g., Verhaeghen \& Salthouse, 1997; Ritchie et al., 2016).

Hutteman et al. (2014) posit culturally constrained life tasks that change in predictable ways with age within the five domains. For instance, within the romantic relationship domain, the typical pattern (at least in contemporary Western societies) is for individuals to locate a suitable long-term partner during adolescence/early adulthood, adjust to living with that partner during early adulthood, work to maintain a high quality relationship during middle adulthood, and then to adjust to the loss of a spouse toward the end of life. These shifts in developmental tasks would likely translate into changes in the salience of Mating and Sociality aspects of situations. However, events associated with developmental tasks can occur at non-normative times in the life span as when a 20 -something experiences the death of committed romantic 
partner or spouse due to illness or injury. ${ }^{1}$

Hutteman et al.’s (2014) typology elegantly details common life tasks and how those tasks progress from early to middle to late adulthood. However, they omitted childhood and adolescence from their considerations. Accordingly, we adopted and expanded their framework in Table 2 and added these phases of life by drawing on earlier work by Erikson (1950) and Masten and Coatsworth (1988) who identified several developmental tasks in childhood and adolescence.

Considering the tasks associated with young adulthood listed in Table 2 illustrates how DIAMONDS can be merged with a life tasks perspective. One of the tasks is to establish an independent home from the family of origin. In many Western societies, it is normative for young adults to establish their own household after finishing compulsory schooling. The exact timing of these life transitions varies depending on culture and context and likely varies with economic conditions. In years past, the typical young adult in the United States lived with either a spouse or a romantic partner independent of their parents. The peak for this arrangement was in 1962 when $62 \%$ of 18 to 34 year-olds were living with a spouse or partner. However, by 2014, the number of young adults living with their parents was actually slightly higher $(32.1 \%)$ than the number living with a spouse or partner (31.6\%; Fry, 2016).

Our point is that a life task such as establishing an independent home can be construed as a marker of a major shift in the daily experience of DIAMONDS situation characteristics. Independent living is likely to produce a series of situations with higher levels of Duty, less Adversity, more pOsitivity, and less Negativity than living with parents. Aside from the issue of

\footnotetext{
${ }^{1}$ Such events are likely to act like the life transitions identified by Caspi and Moffitt (1993) as prompting personality consistency because non-normative events are inherently ambiguous in terms of social norms, scripts, and support for a specific ways of thinking, feeling, and behaving.
} 
living with parents versus living alone or with a romantic partner, evidence suggests that residential mobility is major component of early adulthood (Arnett, 2000; see also Rindfuss, 1991). Recent data from the nationally representative American Community Survey (Benetsky, Burd, \& Rapino, 2015) suggests that moving rates are higher among young adults than in any other age group, with about $31 \%$ of those aged $18-24$ moving within the past year (based on the 2010-2012 estimates). Certainly, these changes in living arrangements shape the situations and situational characteristics of everyday life for young adults. For instance, moving may, at least initially, disrupt social support networks, decreasing Sociality in individuals' daily lives.

Considering these examples, we can see that the sequencing and completion of developmental tasks changes in response to societal and cultural shifts, as well as economic pressures. Regardless, these demographic changes are likely to translate to different situational characteristics as captured by the DIAMONDS framework. Attention to developmental tasks can help identify situations and situational changes that are likely to be important as people age.

All told, we think much can gained by thinking about how developmental tasks impact situational characteristics. The tasks framework highlights key domains of life that are likely to be superordinate contexts for the everyday situations that people will experience throughout their lifetime - romantic relationships, families, jobs and schools, and friendship networks. A developmental tasks perspective also highlights the kinds of motivations that are likely to be salient at different times in the lifespan. For example, issues of establishing an identity and reputation are more salient in adolescence and early adulthood than late life. Age differences in the salience of development tasks will influence the kinds of goals individuals will pursue and which situational features they will attend to in a given situation. Issues of adversity might be salient and even sought after in adulthood, when establishing a career and position in a social 
hierarchy are important, but actively avoided in late life. This possibility raises questions about whether broad goals shift with development and how those goals might influence situations, a topic that is central to another prominent lifespan perspective - socioemotional selectivity theory.

\section{Socioemotional Selectivity Theory}

Socioemotional selectivity theory (SST; Carstensen, Isaacowitz, \& Charles, 1999) is another developmental perspective that seems to have clear implications for person-situation transactions across the life span. The starting point of this theory is the idea that individuals become more aware of how much time they have left to live as they approach the end of their lifespan. Younger people view time as a less limited resource than older people, and this fact has implications for the motivations and goals that individuals pursue in a given situation, as well as the kinds of situations that individuals select.

Two broad goals are central to SST - knowledge goals and emotion regulation goals. Knowledge goals concern acquiring new information about the social and physical world, whereas emotional regulation goals are about managing emotions in the present often with the objective of maximizing pleasant feelings and minimizing unpleasant feelings when interacting with others. According to SST, people pursue both of these goals across the lifespan, but knowledge goals are privileged when individuals have lots of time left (i.e., earlier in the lifespan), whereas emotional regulation goals are privileged when time left is perceived to be more scarce (i.e., later in the lifespan).

A key prediction from SST is that younger people, when compared to older individuals, are more interested in interacting with others to gain knowledge about the world so that they can adapt to future challenges, capitalize on future opportunities, and avoid potential pitfalls. When 
time is seemingly expansive, individuals will focus on maximizing the amount of knowledge that can be extracted from the world. The objective is to prepare for the future. Older people have typically already amassed considerable knowledge about the world and do not have as a long of a future window as younger people. Thus, gaining additional knowledge about the world holds less utility for older individuals than younger individuals. Older people instead are more motivated to focus on their present emotional states to accentuate pleasant and meaningful feelings and to avoid unpleasant emotional experiences. When time is limited, individuals will focus on maximizing the emotional quality of life. The objective is to obtain momentary satisfaction.

We believe that SST makes predictions that can be understood within the DIAMONDS framework. Broadly speaking, older individuals should place more emphasis on selecting situations with relatively high levels of pOsitivity and Sociality (especially social interactions with close and cherished interaction partners) and relatively low levels of Negativity, Adversity, and Deception. These predictions follow directly from the SST postulate concerning motivational changes with respect to emotional regulation. The DIAMONDS dimensions of pOsitivity and Negativity are predicted to be less important to younger people than older people, especially if opportunities for learning new things, meeting new people, and generally expanding social networks and coalitions are present. The Intellect dimension should be less important with age given the diminished utility of knowledge according to SST. That is, younger people will emphasize the knowledge dimension because of the utility of knowledge when the time horizon is expansive according to SST.

In short, SST can be used to make some interesting predictions about the situational factors that individuals will differentially value as they age because of changing motivational dynamics. This insight underscores the reality that individuals select situations based in part, on 
internal psychological factors. The process of situational selection is one important type of person-situation transaction, and we now turn to an explicit discussion of different types of transactions.

\section{Types of Person-Situation Transactions Across the Lifespan}

A developmental perspective is useful for defusing any remaining tensions about the relative importance of dispositional versus situational factors for producing behavior by shifting the question from debating which factor is more important to understanding how both work together to produce behavior. It seems uncontroversial to note that certain people tend to interpret situations in often idiosyncratic, yet predictable, ways (situational construal), elicit specific kinds of reactions from others (situational elicitation), and select themselves into and out of situations to achieve a closer match between dispositional and situational features (situational selection). These three processes - construal, elicitation, and selection - tend to produce phenotypic consistencies and may even promote behavioral consistency over time (e.g., Caspi \& Bem, 1991; Roberts et al., 2012). In contrast, a different set of mechanisms (shifting reward and punishment structures; self-reflection) can produce behavioral discontinuities. We identify different types of person-situation transactions in this section.

\section{Processes that Promote Consistency}

Situational Construal. Dispositions influence how people perceive situations. For example, some people are more sensitive to threat than others and might perceive ambiguous social stimuli in ways that indicate hostility and intention to do harm. This is known as the hostile attribution bias (e.g., Dodge, 1986) or hostile attribution of intent (de Castro, Veerman, Koops, Bosch, \& Monshouwer, 2002) in the developmental literature. Situational construal and situational elicitation often work in tandem to produce self-fulfilling cycles. For instance, a 
tendency to attribute hostile intent to others can initiate a self-reinforcing cycle whereby individuals interpret ambiguous social cues (such as a minor encroachment on personal space or accidently knocking over toys) as indicators of hostility, resulting in a response to these ambiguous cues of lashing out. This response to the situational construal will often evoke hostility in others. Downey, Freitas, Michaelis, and Khouri (1988) provide a conceptually similar account of how rejection sensitivity can set in motion self-fulfilling cycles whereby a tendency to expect rejection from a romantic partner can eventually stimulate rejection because rejection sensitive individuals undermine their partner's satisfaction with the relationship.

A key issue is to map particular personality elements to perceptions of particular DIAMONDS dimensions. Studies using earlier types of situational assessment (for instance, the Riverside Situational Q-Sort or RSQ) suggest that such mapping will be fruitful (e.g., Serfass \& Sherman, 2012; Sherman, Nave, \& Funder, 20120. However, work with the DIAMONDS dimensions has yet to be published.

Situational Elicitation. Dispositions can draw out or elicit predictable reactions from the environment (Buss, 1987). This insight is also captured by the concept of evocative genotype-environment interactions (Scarr \& McCartney, 1983). A classic developmental study by Anderson, Lytton, and Romney (1986) illustrates this general principle with respect to parentchild interactions that seem relevant to the DIAMONDS dimension of Adversity. These authors recruited 18 mother-son dyads where the child had a diagnosis of conduct disorder (CD) and 18 mother-son dyads where the child did not have such a diagnosis. The mothers then interacted with their own child, another child with $\mathrm{CD}$, and a child without $\mathrm{CD}$. The basic finding was that the boys with CD evoked more negative and coercive behaviors from the women in the study. 
The authors concluded that the adult-child interactions were "driven mainly by the child" (p. 607).

The basic Anderson et al. (1986) finding was conceptually replicated by Ge et al. (1996) using an adoption design. In this study, information about biological parents was collected and then adopted adolescents and their adoptive parents were observed interacting in structured discussion tasks. Adolescents whose biological parent had an externalizing disorder (and thus had a presumably greater genetic propensity for impulse control issues) evoked harsh discipline and low warmth from their adoptive parents. Such an effect was not found for adopted adolescents with biological parents who did not have externalizing disorders. Collectively, these studies provide evidence that, at least in cases with extreme behavioral phenotypes, children and adolescents may elicit specific and predictable reactions from adults related to Adversity. Such dynamic accounts of mutual dyadic-influence between parent and child challenge simplistic accounts that suggest that the direction of effect is always parent-to-child (see e.g., Bell, 1968), a sentiment that occasionally pervades even contemporary developmental studies.

Another important idea embedded in the idea of situational elicitation is that parents represent a situational cue for children and vice versa. That is, consistent with the DIAMONDS framework (Rauthmann et al., 2014) and our meta-theoretical assumptions, features of the social environment - especially other people - are associated with particular psychological characteristics of situations. Not all children evoke similar amounts of adversity for parents. Indeed, situations are often complex because all of the relevant participants contribute to the psychologically relevant elements of the situation by acting and reacting to one another.

Situational Selection. Scarr and McCartney (1983) noted that individuals are increasingly able to go about niche picking and building as they mature from infancy to 
adulthood. Cesario, Grant, and Higgins (2004) suggested that individuals are more likely to simply feel right when situational and dispositional forces are in synchrony. This fit likely provides a hedonic impetus for selecting particular environments over others. Once individuals find themselves in situations that match with their dispositions, a self-reinforcing cycle ensues. A shy person who selects a solitary job will not frequently encounter contexts that push, pull, or otherwise require sociability. By contrast, an extraverted person who seeks out a job in sales will frequently encounter contexts that push, pull, and seemingly demand sociability. This general developmental process of niche picking and situational selection is likely an important mechanism that explains why the heritability of personality increases with age (e.g., Briley \& Tucker-Drob, 2015).

As individuals change in autonomy, we might expect a greater or lesser correspondence between personality characteristics and situational features. Indeed, we predict shifts with age toward greater correspondence. The advent of the DIAMONDS framework provides a tool to study this issue by providing a useful taxonomy of situational features to test this issue. It seems possible to match dispositions with specific DIAMONDS dimensions to more precisely study situational selection.

\section{Processes that Promote Change}

Though many person-situation transactions seem to promote consistency in individuals' characteristics, different transactions can produce change. These include shifting reward and punishment structures and self-reflection. To be sure, the most basic behaviorist insight about human nature appears to have a degree of validity: People will respond to situational contingencies. Rewards and punishments can be powerful techniques for influencing behavior. 
Moreover, sometimes people want to change themselves, and we suspect that actively seeking certain kinds of situational features might help people change.

Reward and punishment. Although individuals do their best to control their environments and the situations they experience, not all experiences are controllable and autonomy is never complete. Accidents happen and situational demands change with development and life events. Although there is an underlying current of stability in personality trait levels even in the context of relatively extreme disruptions to daily life (e.g., Luhmann et al., 2012), there have been some noted exceptions. For instance, Bardi and colleagues (Bardi, Buchanan, Goodwin, Slabu, \& Robinson, 2014) found evidence of larger changes in values following international migration, which involves a complete restructuring of daily life, when compared to smaller life changes (such as choosing a college major or being trained as a police officer). Likewise, a recent meta-analysis suggests personality changes are possible with therapy and other interventions (Roberts, Luo, Briley, Chow, Su, \& Hill, in press).

Changes in personality might occur as life events reshape individuals' daily experiences and exposure to rewards and punishments (Wrzus \& Roberts, in press). For example, consider the changes that occur to an employee following a layoff. Prior to being laid off, the employee followed a set schedule - waking up at 6 am to exercise before taking children to school and going to sleep at reasonable time to have the energy to perform required duties. The employee would be subjected to praise from supervisors for successful task performance and given financial bonuses for working hard. The threat of disciplinary action and being fired were also potential motivators of high performance. The workplace might also be a network of key friendships and social support. These are forces that would tend to promote conscientious 
behaviors and psychological well-being, in the context of situations high in the characteristics of Duty, Intellect, pOsitivity, and Sociality, as well as low in Negativity.

After the job loss, however, the once predictable system of reinforcements and punishments are dramatically shifted as daily structure is removed. The individual must also adapt to an identity shift as the role of a 20-year employee of a given organization is no longer relevant. The opportunities to demonstrate competence and develop skills are gone. Income also drops, and individuals have increased concerns about financial security. Contact with social networks is shifted and measures to save money, such as cutting gym memberships, may alter health habits and further limit exposure to friends and acquaintances. Changes to work life have pervasive influence on the situations faced by the individual in this example. We can expect decreases in pOsitivity, Duty, Intellect, and Sociality, and increases in Negativity, and perhaps Adversity.

If the aftermath of unemployment persists, we might predict there could be changes in personality for the individual. Consistent with these speculations, Boyce and colleagues found changes in personality following unemployment in a large German sample. They compared individuals who experienced lengthy unemployment (one to four years) with individuals who remained employed or were re-employed after brief unemployment. Results showed that conscientiousness and openness demonstrated larger than normative decreases following unemployment (Boyce, Wood, Daly, \& Sedikides, 2015).

Overall, there remains much to learn concerning the association between major situational changes and longstanding personality trait change (see Bleidorn, Hopwood, \& Lucas, in press, for a review). Nonetheless, major life events often entail relatively large changes in the kinds of rewards and punishments that individuals experience on a regular basis and these 
changes seem to have the potential to lead to long-term changes in personality. A focus on the specific features of situations may help researchers refine their understanding of the process through which situations change personality attributes.

Self-reflections and motivated change. Individuals do not always like all of their personality characteristics (Hudson \& Roberts, 2014). Individuals often have change goals or goals to increase their desirable personality traits (e.g., industriousness) and decrease their undesirable traits (e.g., anxiety). Recent research has shown that change goals themselves often shift over the course of development, with young adults endorsing goals to change personality traits more strongly than older individuals (Hudson \& Fraley, 2016) perhaps to better maximize the fit between the demands of the situation and the characteristics of the individual. Nonetheless, the goal to change one's characteristics appears to be a persistent theme over the lifespan.

Are people who want to change their traits ultimately successful in doing so? Some evidence from clinical psychology suggests that personality trait change happens (e.g., Roberts et al., in press). Moreover, various types of psychotherapy have been found to be associated with decreases in anxiety and depression (see, e.g., Dobson et al., 2008). In non-clinical work, a recent pair of 16-week longitudinal studies found that goals to change levels of five factor model traits predicted subsequent trait change in the desired direction (Hudson \& Fraley, 2015). Thus, individuals might be able to change themselves when motivated and supported by others.

Of interest for understanding change goals in the context of situational changes over development is a recent study that examined individuals' perceptions of the reasons behind (1) trait changes already perceived to have occurred and (2) desired future trait changes (Baranski, Morse, \& Dunlap, in press). Social roles, important others' expectations, and other situational 
characteristics could all be important predictors of real or perceived changes in personality, as well as motivators of the desire to change in the future.

Participants in the Baranski et al. (in press) study were asked to reflect on "an experience or period" in their lives that precipitated a desire to change a trait, as well as an experience or period that seemingly caused perceived change in a trait in the past. Researchers then coded participants' open-ended responses to these two questions as specific events (e.g., being called into a supervisor's office), specific shifts in social roles (e.g., beginning college or having a baby), or general life periods (i.e., slow gradual change). Results showed that $54 \%$ of participants attributed past perceived personality changes to a shift in a social role, whereas $52 \%$ attributed current desires to change to a specific event. Furthermore, only $18 \%$ of participants perceived past changes to stem from their own volition (but the authors did not code current desires to change on this dimension). These results suggest that people don't necessarily consider their past trait changes to be self-authored. That is, many reasons to change are perceived to come from outside the person. Thus situational changes may be both the real and the perceived impetus for change, and future research will be required to tease apart the extent to which either or both of these possibilities is supported.

\section{Conclusions, Future Directions, and Closing Thoughts}

The objective of this chapter was to provide a developmental perspective on personsituation transactions. Research and theorizing on this topic are poised to make critical gains given the increased attention to situational factors in social/personality psychology (e.g., Rauthmann, Sherman, \& Funder, 2014). We believe that developmental perspectives can help researchers who specialize in situational features pay attention to how those features shift with age and remind researchers that people may want different things from their situations as they 
age. Collectively, these considerations underscore the reality that human development features complex transactions between people and situations.

Having considered important principles of personality development, developmental tasks, socioemotional selectivity theory, and the processes of person-situation transactions in the context of the situational characteristics (the eight DIAMONDS), we turn now to consider a few key future directions for understanding situations developmentally - one methodological and a second substantive.

First and foremost, longitudinal investigations of the DIAMONDS situational features across developmental periods are warranted. Doing so will enable researchers to directly examine the stability and change of situational characteristics (i.e., their differential and meanlevel stability and change). Existing evidence suggests that situational characteristics will show high levels of differential stability (especially in midlife; see e.g., Kandler, 2012) and normative mean-level changes. However, it remains to be seen whether (1) levels of stability for each dimension approach that of personality traits, and (2) whether the pattern of normative changes in each DIAMONDS dimension mimics the changes typically observed for conceptually related traits (e.g., to what extent do duty and Conscientiousness show similar patterns of change?).

Existing statistical techniques for longitudinal data (e.g., latent growth curves) can be applied to the study of situational characteristics. Moreover, traits and situations can be modeled together to examine the extent to which changes in traits and situations tend to co-vary. Sherman et al.'s (2015) research showed that situational characteristics predict personality states, but it did not examine whether states predict future situations - an interesting, but different question. Over a longer term study, we might predict that personality states could indeed predict future situations. For instance, an interpersonally difficult boss might be associated with situational 
Negativity and Adversity, which might predict higher levels of state anxiety and negative affect. Such experiences might motivate an individual to make a change - by looking for a new job or perhaps moving to a new region - ultimately precipitating changes in future situations and personality states. These changes are probably difficult to observe in a short-term study, but might be more apparent in the longer term. This is just one possible question that researchers could investigate in a longer term study of change.

A complicating factor for future research is the notion that situational characteristics should be assessed by more than one person (what Rauthmann et al., 2015 called the approximation corollary) to avoid confounding situational characteristics with perceiver traits. Thus perhaps even more so than for a typical developmental study, a well-designed developmental study of situational characteristics will require substantial resources, in addition to creative design.

Overall, however, the future looks very bright for the study of situations in developmental context. Advances in technology have made repeated assessment of individuals in their natural environments easier and less invasive. Tools such as the Electronically Activated Recorder (Mehl, Pennebaker, Crow, Dabbs, \& Price, 2001) for audio assessment and smartphone sensors for detecting environmental data and digital footprints (Harari, Gosling, Wang, \& Campbell, 2015) stand to transform our understanding of situations. Indeed, we are excited about how advances in technology will help researchers better study persons and situations over time.

Moreover, as reviewed earlier in our consideration of life tasks, cultural, social, and economic factors help construct the stage for the consideration of person-situation transactions. One major factor sociocultural factor that deserves further study in the future is online situations. 
The internet will soon begin its third decade of existence, and much of modern life now takes place fully online and thus in so-called virtual situations. Future research might examine to what extent online situations are simply mirrors of face-to-face interactions and in what key ways they differ. Situational Adversity, for instance, may have a higher prevalence rate in relatively impersonal online interactions. As so-called 'digital natives' (i.e., individuals who grew up with heavy exposure to and use of digital technologies) grow older, they may opt out of digital communities (i.e., situational selection) if such communities do not provide sufficient Positivity and minimal Negativity, consistent with the predictions of socioemotional selectivity theory. Regardless - digital situations present an interesting venue for future study.

In closing, we hope the researchers who are excited about the psychology of situations also incorporate developmental considerations into their work. We think developmental insights about patterns of personality stability and change across the lifespan, as well as the different themes and motivations that are salient at different periods of the lifespan, provide clues about how situational factors work with dispositions to produce human development. The promise of working taxonomies of situational characteristics is that they help make future research and theorizing about person-situation transactions across the lifespan much more precise and testable. The future looks bright for researchers interested in personality and situational development. 


\section{References}

Anderson, K. E., Lytton, H., \& Romney, D. M. (1986). Mothers' interactions with normal and conduct-disordered boys: Who affects whom? Developmental Psychology, 22, 604-609.

Anusic, I., \& Schimmack, U. (2016). Stability and change of personality traits, self-esteem, and well-being: Introducing the meta-analytic stability and change model of retest correlations, 110, 766-781.

Arnett, J. J. (2000). Emerging adulthood: A theory of development from the late teens through the twenties. American Psychologist, 55, 469-480.

Ashton, M. C., \& Lee, K. (2007). Empirical, theoretical, and practical advantages of the HEXACO model of personality structure. Personality and Social Psychology Review, 11, $150-166$.

Ashton, M. C., \& Lee, K. (2016). Age trends in HEXACO-PI-R self-reports. Journal of Research in Personality, 64, 102-111.

Baranski, E. N., Morse, P. J., \& Dunlap, W. L. (In press). Lay conceptions of volitional personality change: From strategies pursued to stories told. Journal of Personality. doi: 10.1111/jopy. 12240

Baltes, P. B., Staudinger, U. M., \& Lindenberger, U. (1999). Lifespan psychology: Theory and application to intellectual functioning. Annual Review of Psychology, 50, 471-507.

Baltes, P. B., Lidenberger, U., \& Staudinger, U. M. (2006). Life span theory in developmental psychology. In W. Damon \& R.M. Lerner (Eds.). Handbook of child psychology, volume one: Theoretical models of human development ( $6^{\text {th }}$ ed.), pp. 569-664. New York: John Wiley \& Sons, Inc. 
Bardi, A., Buchanan, K. E., Goodwin, R., Slabu, L., \& Robinson, M. (2014). Value stability and change during self-chosen life transitions: Self-selection versus socialization effects. Journal of Personality and Social Psychology, 106, 131-147.

Bell, R. Q. (1968). A reinterpretation of the direction of effects in studies of socialization. Psychological Review, 75, 81-95.

Bell, R. Q., \& Chapman, M. (1986). Child effects in studies using experimental or brief longitudinal approaches to socialization. Developmental Psychology, 22, 595-603.

Benetsky, M. J., Burd, C., \& Rapino, M. (2015). Young adult migration: 2007-2009 to 20102012. American Community Survey Reports, ACS-31, U.S. Census Bureau, Washington, DC. Retrieved from https://www.census.gov/content/dam/Census/library/publications/2015/acs/acs-31.pdf.

Bleidorn, W., Hopwood, C. J., \& Lucas, R. E. (in press). Life events and personality trait change. Journal of Personality. doi: 10.1111/jopy.12286

Bowers, K. S. (1973). Situationism in psychology. Psychological Review, 80, 307-336.

Boyce, C. J., Wood, A. M., Daly, M., \& Sedikides, C. (2015). Personality change following unemployment. Journal of Applied Psychology, 100, 991-1011.

Briley, D. A., \& Tucker-Drob, E. M. (2014). Genetic and environmental continuity in personality development: A meta-analysis. Psychological Bulletin, 140, 1303-1331.

Brown, N. A., \& Rauthmann, J. F. (2016). Situation characteristics are age graded: Mean-level patterns of the situational eight DIAMONDS across the lifespan. Social Psychological and Personality Science, 7, 667-679.

Buss, D. M. (1987). Selection, evocation, and manipulation. Journal of Personality and Social Psychology, 53, 1214-1221. 
Caspi, A. (1998). Personality development across the life course. In W. Damon (Series Ed.) \& N. Eisenberg (Vol. Ed.), Handbook of child psychology, Volume 3: Social, emotional, and personality development ( $5^{\text {th }}$ ed., pp. 311-388). New York: Wiley.

Caspi, A., \& Bem, D. J. (1990). Personality continuity and change across the life course. In L. Pervin (Ed.), Handbook of personality: Theory and research (pp. 549-575). New YorK: Guilford Press.

Caspi, A., Elder, G. H., Jr., \& Bem, D. J. (1989). Continuities and consequences of interactional styles across the life course. Journal of Personality, 57, 375-406.

Caspi, A., \& Moffitt, T. E. (1993). When do individual differences matter? A paradoxical theory of personality coherence. Psychological Inquiry, 4, 247-271.

Caspi, A., Moffitt, T. E., Newman, D. L., \& Silva, P. A. (1996). Behavioral observations at age 3 years predict adult psychiatric disorders: Longitudinal evidence from a birth cohort. Archives of General Psychiatry, 53, 1033-1039.

Caspi, A., \& Roberts, B. W. (2001). Personality development across the life course: The argument for change and continuity. Psychological Inquiry, 12, 49-66.

Caspi, A., Roberts, B. W., \& Shiner, R. L. (2005). Personality development: Stability and change. Annual Review of Psychology, 56, 453-484.

Caspi, A., \& Shiner, R. L. (2006). Personality development. In W. Damon \& R. M. Lerner (Series Eds.) \& N. Eisenberg (Vol. Ed.), Handbook of child psychology, Volume 3: Social, emotional, and personality development (6 ${ }^{\text {th }}$ ed., pp. 300-365). New York: Wiley. Carstensen, L. L., Isaacowitz, D. M., \& Charles, S. T. (1999). Taking time seriously: A theory of socioemotional selectivity. American Psychologist, 54, 165-181. 
Cesario, J., Grant, H., \& Higgins, E. T. (2004). Regulatory fit and persuasion: Transfer from “feeling right”. Journal of Personality and Social Psychology, 86, 388-404.

Chess, S., \& Thomas, A. (1977). Temperament individuality from childhood to adolescence. Journal of the American Academy of Child Psychiatry, 16, 218-226.

Clark, L. A., \& Watson, D. (2008). Temperament: An organizing paradigm for trait psychology. In O. P. John, R. W. Robins, and L. A. Pervin (Eds.). Handbook of personality: Theory and Research ( $3^{\text {rd }}$ ed., pp. 265-286). New York: Guilford Press.

Conley, J. J. (1984). Longitudinal consistency of adult personality: Self-reported psychological characteristics across 45 years. Journal of Personality and Social Psychology, 47, 13251333.

Cooper, W. H., \& Withey, M. J. (2003). The strong situation hypothesis. Personality and Social Psychology Review, 13, 62-72.

Corker, K.S., Donnellan, M. B., \& Bowles, R. P. (2013). The development of achievement goals throughout college: Modeling stability and change. Personality and Social Psychology Bulletin, 39, 1401-1417.

de Castro, B. O., Veerman, J. W., Koops, W., Bosch, J. D., \& Monshouwer, H. J. (2002). Hostile attribution of intent and aggressive behavior: A meta-analysis. Child Development, 73, 916-934.

Digman, J. M. (1990). Personality structure: Emergence of the five-factor model. Annual Review of Psychology, 41, 417-440.

Dobson, K. S., Hollon, S. D., Dimidjian, S., Schmaling, K. B., Kohlenberg, R. J., Gallop, R. J., Rizvi, S. L., Gollan, J. K., Dunner, D. L., \& Jacobson, N. S. (2008). Randomized trial of behavioral activation, cognitive therapy, and antidepressant medication in the prevention 
of relapse and recurrence in major depression. Journal of Consulting and Clinical Psychology, 76, 468-477.

Donnellan, M. B., \& Lucas, R. E. (2008). Age differences in the Big Five across the life span: Evidence from two national samples. Psychology and Aging, 23, 558-566.

Downey, G., Freitas, A. L., Michaelis, B., \& Khouri, H. (1988). The self-fulfilling prophesy in close relationships: Rejection sensitivity and rejection by romantic partners. Journal of Personality and Social Psychology, 75, 545-560.

Elder Jr., G. H. \& Shanahan, M. J. (2006). The life course and human development. In W. Damon \& R. M. Lerner (Eds.). Handbook of child psychology, volume one: Theoretical models of human development ( $6^{\text {th }}$ ed.), pp. 665-715. New York: John Wiley \& Sons, Inc.

Epstein, S., \& O’Brien, E. J. (1985). The person-situation debate in historical and current perspective. Psychological Bulletin, 98, 513-537.

Erikson, E. H. (1950). Childhood and society. New York: Norton.

Eysenck, H. J. (1991). Dimensions of personality: 16, 5 or 3? Criteria for a taxonomic paradigm. Personality and Individual Differences, 12, 773-790.

Ferguson, C. J. (2010). A meta-analysis of normal and disordered personality across the life span. Journal of Personality and Social Psychology, 98, 659-667.

Fraley, C., \& Roberts, B. W. (2005). Patterns of continuity: A dynamic model for conceptualizing the stability of individual differences in psychological constructs across the life course. Psychological Review, 112, 60-74.

Fry, R. (2016, May). For first time in modern era, living with parents edges out other living arrangements for 18- to 34-Year-Olds. Washington, D.C.: Pew Research Center. Retrived 
from http://www.pewsocialtrends.org/2016/05/24/for-first-time-in-modern-era-livingwith-parents-edges-out-other-living-arrangements-for-18-to-34-year-olds/

Ge, X., Conger, R. D., Cadoret, R. J., Neiderhiser, J. M., Yates, W., Troughton, E., \& Stewart, M. A. (1996). The developmental interface between nature and nurture: A mutual influence model of child antisocial behavior and parent behaviors. Developmental Psychology, 32, 574-589.

Gignac, G. E., \& Szodorai, E. T. (2016). Effect size guidelines for individual differences researchers. Personality and Individual Differences, 102, 74-78.

Harari, G. M., Gosling, S., Wang, R., \& Campbell, A. T. (2015). Capturing situational information with smartphones and mobile sensing methods. European Journal of Personality, 29, 509-511.

Hudson, N. W., \& Fraley, R. C. (2016). Do people's desires to change their personality traits vary with age? An examination of trait change goals across adulthood. Social Psychological and Personality Science, 7, 847-856.

Hudson, N. W., \& Roberts, B. W. (2014). Goals to change personality traits: Concurrent links between personality traits, daily behavior, and goals to change oneself. Journal of Research in Personality, 53, 68-83.

Hutteman, R., Hennecke, M., Orth, U., Reitz, A. K., \& Specht, J. (2014). Developmental tasks as a framework to study personal- ity development in adulthood and old age. European Journal of Personality, 28, 267-278.

Ickes, W., Snyder, M., \& Garcia, S. (1997). Personality influences on the choice of situations. In R. Hogan, J. A. Johnson, \& S. R. Briggs (Eds.) Handbook of personality psychology (pp. 165-195). San Diego: Academic Press 
James, W. (1890). The principles of psychology. New York: Henry Holt \& Co.

Kandler, C. (2012). Nature and nurture in personality development: The case of neuroticism and extraversion. Current Directions in Psychological Science, 21, 290-296.

Kenrick, D. T., \& Funder, D. C. (1988). Profiting from controversy: Lessons from the personsituation debate. American Psychologist, 43, 23-34.

Lee, K., \& Ashton, M. C. (in press). Psychometric Properties of the HEXACO-100. Assessment.

Lucas, R. E., \& Donnellan, M. B. (2011). Personality development across the life span: Longitudinal analyses with a national sample from Germany. Journal of Personality and Social Psychology, 101, 847-861.

Luhmann, M., Hofmann, W., Eid, M., \& Lucas, R. E. (2011). Subjective well-being and adaptation to life events: A meta-analysis. Journal of Personality and Social Psychology, $102,592-615$.

Magnusson, D., \& Stattin, H. (2006). The person in context: A holistic-interactionist approach. In W. Damon \& R.M. Lerner (Eds.). Handbook of child psychology, volume one: Theoretical models of human development ( $6^{\text {th }}$ ed.), pp. 400-464. New York: John Wiley \& Sons, Inc.

Masten, A. S., \& Coatsworth, J. D. (1998). The development of competence in favorable and unfavorable environments. American Psychologist, 53, 205-220.

Mayer, J. D. (2005). A tale of two visions: Can a new view of personality help integrate psychology?. American Psychologist, 60, 294-307.

McAdams, D. P. (2001). The psychology of life stories. Review of General Psychology, 5, 100122.

McAdams, D. P. (2015). The art and science of personality development. New York: Guilford. 
McAdams, D. P. \& Olson, B. D. (2010). Personality development: Continuity and change over the life course. Annual Review of Psychology, 61, 517-542.

McAdams, D. P., \& Pals, J. L. (2006). A new Big Five: Fundamental principles for an integrative science of personality. American Psychologist, 61, 204-217.

McCrae, R. R., \& Costa, P. T., Jr. (2008). The five-factor theory of personality. In O. P. John, R. W. Robins, \& L. A. Pervin (Eds.), Handbook of personality: Theory and research (3rd ed., pp. 157-180). New York: Guilford.

Mehl, M. R., Pennebaker, J. W., Crow, D. M., Dabbs, J., \& Price, J. H. (2001). The electronically activated recorder (EAR): A device for sampling naturalistic daily activities and conversations. Behavior Research Methods, Instruments, and Computers, 33, $517-$ 523.

Moffitt, T. E., Arseneault, L., Belsky, D., Dickson, N., Hancox, R. J., Harrington, H., ... Caspi., A. (2011). A gradient of childhood self-control predicts health, wealth, and public safety, Proceedings of the National Academy of Sciences, 108, 2693-2698.

Mund, M., Finn, C., Hagemeyer, B., \& Neyer, F. J. (2016). Understanding dynamic transactions between personality traits and partner relationships. Current Directions in Psychological Science, 25, 411-416.

Olweus, D. L. (1979). The stability of aggressive reaction pattern in males: A review. Psychological Bulletin, 86, 852-875.

Nave, C. S., Sherman, R. A., Funder, D. C., Hampson, S. E., \& Goldberg, L. R. (2010). On the contextual independence of personality: Teachers' assessments predict directly observed behavior after four decades. Social Psychological and Personality Science, 1, 327-334.

Pinker, S. (2003). The blank slate: The modern denial of human nature. New York: Penguin 
Books.

Plomin, R., DeFries, J. C., \& Loehlin, J. C. (1977). Genotype-environment interaction and correlation in the analysis of human behavior. Psychological Bulletin, 84, 309-322.

Rauthmann, J. F., Gallardo-Pujol, D., Guillaume, E. M., Todd, E., Nave, C. S., Sherman, R. A., Ziegler, M., *Jones, A. B., \& Funder, D. C. (2014). The situational eight DIAMONDS: A taxonomy of major dimensions of situation characteristics. Journal of Personality and Social Psychology, 107(4), 677-718.Rauthmann, J. F., Sherman, R. A., \& Funder, D. C. (2015). Principles of situation research: Towards a better understanding of psychological situations. European Journal of Personality, 29, 363-381.

Reis, H. T. (2008). Reinvigorating the concept of situation in social psychology. Personality and Social Psychology Review, 12, 311-329.

Reis, H. T., Collins, W. A., \& Berscheid, E. (2000). The relationship context of human behavior and development. Psychological Bulletin, 126, 844-872.

Rindfuss, R. R. (1991). The young adult years: Diversity, structural change, and fertility. Demography, 28, 493- 512.

Ritchie, S. J., Tucker-Drob, E. M., Cox, S. R., Corley, J., Dykiert, D., Redmond, P., Pattie, A., Taylor, A. M., Sibbett, R., Starr, J. M., \& Deary, I. J. (2016). Predictors of ageing-related decline across multiple cognitive functions. Intelligence, 59, 115-126.

Roberts, B. W., Kuncel, N. R., Shiner, R., Caspi, A., \& Goldberg, L. R. (2007). The power of personality: The comparative validity of personality traits, socioeconomic status, and cognitive ability for predicting important life outcomes. Perspectives on Psychological Science, 2, 313-345 
Rowe, D. C. (1987). Resolving the person-situation debate: Invitation to an interdisciplinary dialogue. American Psychologist, 42, 218-227.

Roberts, B. W. (2006). Personality development and organizational behavior. Research in Organizational Behavior, 27, 1-40.

Roberts, B. W., \& DelVecchio, W. F. (2000). The rank-order consistency of personality traits from childhood to old age: A quantitative review of longitudinal studies. Psychological Bulletin, 126, 3-25.

Roberts, B. W., Donnellan, M. B., \& Hill, P. L. (2012). Personality trait development in adulthood: Findings and implications. In I. B. Weiner (Editor-in-Chief) \& H. Tennen (Vol. Ed.), Handbook of psychology: Vol. 5. Personality and social psychology. New York, NY: Wiley.

Roberts, B. W., Luo, J., Briley, D. A., Chow, P. I., Su, R. \& Hill, P. L. (in press). A systematic review of personality trait change through intervention. Psychological Bulletin.

Roberts, B. W., \& Pomerantz, E. M. (2004). On traits, situations, and their integration: A developmental perspective. Personality and Social Psychology Review, 8, 402- 416.

Roberts, B. W., Walton, K. \& Viechtbauer, W. (2006). Patterns of mean-level change in personality traits across the life course: A meta-analysis of longitudinal studies. Psychological Bulletin, 132, 1-25.

Roberts, B. W., \& Wood, D. (2006). Personality development in the context of the NeoSocioanalytic Model of personality (Chapter 2, pp. 11-39). In D. Mroczek \& T. Little (Eds.), Handbook of Personality Development. Mahwah, NJ: Lawrance Erlbaum Associates. 
Roberts, B. W., Wood, D, \& Caspi, A. (2008). Personality Development. In O.P. John, R.W. Robins, \& L. A. Pervin (Eds.), Handbook of personality: theory and research ( $^{\text {rd }}$ edition, Chapter 14, pp. 375-398). New York, NY: Guilford.

Rothbart, M. K. (2011). Becoming who we are: Temperament and personality in development. New York: Guilford Press.

Scarr, S., \& McCartney, K. (1983). How people make their own environments: A theory of genotype $\rightarrow$ environment effects. Child Development, 54, 424-435.

Scalco, M. D., Trucco, E. M., Coffman, D. L., \& Colder, C. R. (2015). Selection and socialization effects in early adolescent alcohol use: A propensity score analysis. Journal of Abnormal Child Psychology, 43, 1131-1143.

Serfass, D. G., \& Sherman, R. A. (2012). Personality and perceptions of situations from the Thematic Apperception Test. Journal of Research in Personality, 47, 708-718.

Sherman, R. A., Nave, C. N., \& Funder, D. C. (2012). Properties of persons and situations related to overall and distinctive personality-behavior congruence. Journal of Research in Personality, 46, 87-101.

Sherman, R. A., Rauthmann, J. F., Brown, N. A., Serfass, D. G., \& Jones, A. B. (2015). The independent effects of personality and situations on real-time expressions of behavior and emotion. Journal of Personality and Social Psychology, 109, 872-888.

Shiner, R. L. (2009). The development of personality disorders: Perspectives from normal personality development in childhood and adolescence. Development and psychopathology, 21, 715-734.

Shiner, R. L., Buss, K. A., McClowry, S. G., Putnman, S. P., Saudino, K. J., \& Zentner, M. (2012). What is temperament now? Assessing progress in temperament research on the 
twenty-fifth anniversary of Goldsmith et al. (1987). Child Development Perspectives, 6, 436-444.

Soto, C. J., John, O. P., Gosling, S. D., \& Potter, J. (2011). Age differences in personality traits from 10 to 65: Big five domains and facets in a large cross-sectional sample. Journal of Personality and Social Psychology, 100, 330-348.

Soto, C. J., \& Tackett, J. L. (2015). Personality traits in childhood and adolescence: Structure, development, and outcomes. Current Directions in Psychological Science, 24, 358-362.

Synder, M. (1983). The influence of individuals on situations: Implications for understanding the links between personality and social behavior. Journal of Personality, 51, 497-516.

Verhaeghen, P., \& Salthouse, T. A. (1997). Meta-analyses of age-cognition relations in adulthood: Estimates of linear and nonlinear age effects and structural models. Psychological Bulletin, 122, 231-249.

Wrzus, C., \& Roberts, B. W. (In press). Processes of personality development in adulthood: The TESSERA framework. Personality and Social Psychology Review. doi: $10.1177 / 1088868316652279$ 
Table 1

Developmental Considerations in the DIAMONDS Framework

\begin{tabular}{|c|c|c|}
\hline $\begin{array}{l}\text { Situational } \\
\text { Characteristic }\end{array}$ & $\begin{array}{l}\text { Situation } \\
\text { involves... }\end{array}$ & Developmental Considerations \\
\hline Duty & $\begin{array}{l}\text { Work, } \\
\text { responsibilities }\end{array}$ & $\begin{array}{l}\text { Achievement contexts change from school to work } \\
\text { over the lifespan. } \\
\text { Chores and responsibilities increase with age as } \\
\text { individuals develop increased self-regulatory } \\
\text { abilities and are faced with the demands of formal } \\
\text { schooling. }\end{array}$ \\
\hline Intellect & $\begin{array}{l}\text { Thinking, } \\
\text { intellectual } \\
\text { activities }\end{array}$ & $\begin{array}{l}\text { Intellectual activities go from mandatory } \\
\text { (associated with school) to autonomously motivated } \\
\text { after early adulthood. Elementary school students } \\
\text { are asked to learn new things repeatedly but such an } \\
\text { external press is weaker in adulthood. }\end{array}$ \\
\hline Adversity & Conflict, criticism & $\begin{array}{l}\text { Changing power dynamics from early to later } \\
\text { adulthood may imply that adversity is higher earlier } \\
\text { in life than later after greater social status has been } \\
\text { achieved. Individuals can select into more } \\
\text { horizontal or vertically structured organizations. }\end{array}$ \\
\hline Mating & $\begin{array}{l}\text { Romantic } \\
\text { relationships }\end{array}$ & $\begin{array}{l}\text { Early relationships form templates for later } \\
\text { relationships (attachment theory). }\end{array}$ \\
\hline & & $\begin{array}{l}\text { Physical changes at puberty set the stage for } \\
\text { romantic interactions. Mating characteristics might } \\
\text { be less relevant with advancing age given biological } \\
\text { changes. }\end{array}$ \\
\hline pOsitivity & $\begin{array}{l}\text { Positive, pleasant } \\
\text { things }\end{array}$ & $\begin{array}{l}\text { High potential for person-situation transactions. } \\
\text { Older adults might privilege positivity over younger } \\
\text { adults because of how motivational concerns } \\
\text { change as individuals near the end of life } \\
\text { (Socioemotional Selectivity Theory; Carstensen, } \\
\text { Isaacowitz, \& Charles, 1999) }\end{array}$ \\
\hline Negativity & $\begin{array}{l}\text { Negative, } \\
\text { unpleasant things }\end{array}$ & $\begin{array}{l}\text { High potential for person-situation transactions; } \\
\text { changing dynamics over time. Negativity might be } \\
\text { more aversive late in late life (Socioemotional } \\
\text { Selectivity Theory) }\end{array}$ \\
\hline
\end{tabular}




\begin{tabular}{lll}
\hline Deception & $\begin{array}{l}\text { Deceit and } \\
\text { dishonesty }\end{array}$ & $\begin{array}{l}\text { Relatively rare situational characteristic that } \\
\text { nonetheless persists over the life course. Might not } \\
\text { be relevant to youngest age groups. }\end{array}$ \\
Sociality & $\begin{array}{l}\text { Interpersonal } \\
\text { interaction }\end{array}$ & $\begin{array}{l}\text { Balance in the importance of family versus peer } \\
\text { relationships shifts over lifespan. Social networks } \\
\text { shrink after young adulthood. }\end{array}$ \\
\hline
\end{tabular}


Table 2

Developmental Tasks in Childhood and Adolescence

\begin{tabular}{|c|c|c|c|c|}
\hline & \multicolumn{4}{|c|}{ Domains } \\
\hline & Romantic & Family & School/Work & Social \\
\hline \multirow[t]{2}{*}{ Pre-School } & NA & $\begin{array}{l}\text { Learn to follow } \\
\text { family rules and } \\
\text { routines }\end{array}$ & $\begin{array}{l}\text { Learning to } \\
\text { follow the rules } \\
\text { and regulations } \\
\text { of institutions }\end{array}$ & $\begin{array}{l}\text { Learning to } \\
\text { share and } \\
\text { cooperate }\end{array}$ \\
\hline & & $\begin{array}{l}\text { Adjusting to } \\
\text { siblings }\end{array}$ & & $\begin{array}{l}\text { Developing first } \\
\text { friendships }\end{array}$ \\
\hline \multirow[t]{2}{*}{ School-Aged } & NA & $\begin{array}{l}\text { Cultivating a } \\
\text { unique role } \\
\text { within family }\end{array}$ & $\begin{array}{l}\text { Learning basic } \\
\text { academic skills }\end{array}$ & $\begin{array}{l}\text { Making and } \\
\text { keeping friends }\end{array}$ \\
\hline & & $\begin{array}{l}\text { Increasing levels } \\
\text { of responsibility } \\
\text { for own care }\end{array}$ & $\begin{array}{l}\text { Developing a } \\
\text { sense of mastery } \\
\text { and competence }\end{array}$ & $\begin{array}{l}\text { Handling cliques } \\
\text { and gossip }\end{array}$ \\
\hline \multirow[t]{2}{*}{ Adolescence } & $\begin{array}{l}\text { Experiencing first } \\
\text { romantic } \\
\text { relationships }\end{array}$ & $\begin{array}{l}\text { Managing } \\
\text { conflict with } \\
\text { parents }\end{array}$ & $\begin{array}{l}\text { Preparing for } \\
\text { work or higher } \\
\text { education }\end{array}$ & $\begin{array}{l}\text { Managing } \\
\text { relationships } \\
\text { with friends }\end{array}$ \\
\hline & $\begin{array}{l}\text { Dealing with } \\
\text { rejection, } \\
\text { heartbreak }\end{array}$ & $\begin{array}{l}\text { Developing a } \\
\text { sense of } \\
\text { autonomy }\end{array}$ & $\begin{array}{l}\text { Managing } \\
\text { increasing level } \\
\text { of responsibility }\end{array}$ & $\begin{array}{l}\text { Navigating risk } \\
\text { and temptation } \\
\text { (alcohol, drugs) }\end{array}$ \\
\hline \multirow[t]{2}{*}{ Early Adulthood } & $\begin{array}{l}\text { Choosing a long- } \\
\text { term romantic } \\
\text { partner }\end{array}$ & $\begin{array}{l}\text { Having and } \\
\text { raising children }\end{array}$ & $\begin{array}{l}\text { Finishing higher } \\
\text { education }\end{array}$ & $\begin{array}{l}\text { Developing a } \\
\text { network of } \\
\text { friends }\end{array}$ \\
\hline & $\begin{array}{l}\text { Living with a } \\
\text { partner }\end{array}$ & $\begin{array}{l}\text { Establishing an } \\
\text { independent } \\
\text { home }\end{array}$ & $\begin{array}{l}\text { Beginning one's } \\
\text { career } \\
\text { Increasing } \\
\text { involvement in } \\
\text { civic life }\end{array}$ & \\
\hline $\begin{array}{l}\text { Middle } \\
\text { Adulthood }\end{array}$ & $\begin{array}{l}\text { Romantic } \\
\text { relationship } \\
\text { maintenance }\end{array}$ & $\begin{array}{l}\text { Caring for aging } \\
\text { parents } \\
\text { Helping teens to } \\
\text { become } \\
\text { independent }\end{array}$ & $\begin{array}{l}\text { Achieving status } \\
\text { and promotions } \\
\text { in career } \\
\text { Full civic } \\
\text { engagement }\end{array}$ & $\begin{array}{l}\text { Finding hobbies } \\
\text { and leisure } \\
\text { activities } \\
\text { Balancing work } \\
\text { and leisure } \\
\text { activities }\end{array}$ \\
\hline
\end{tabular}




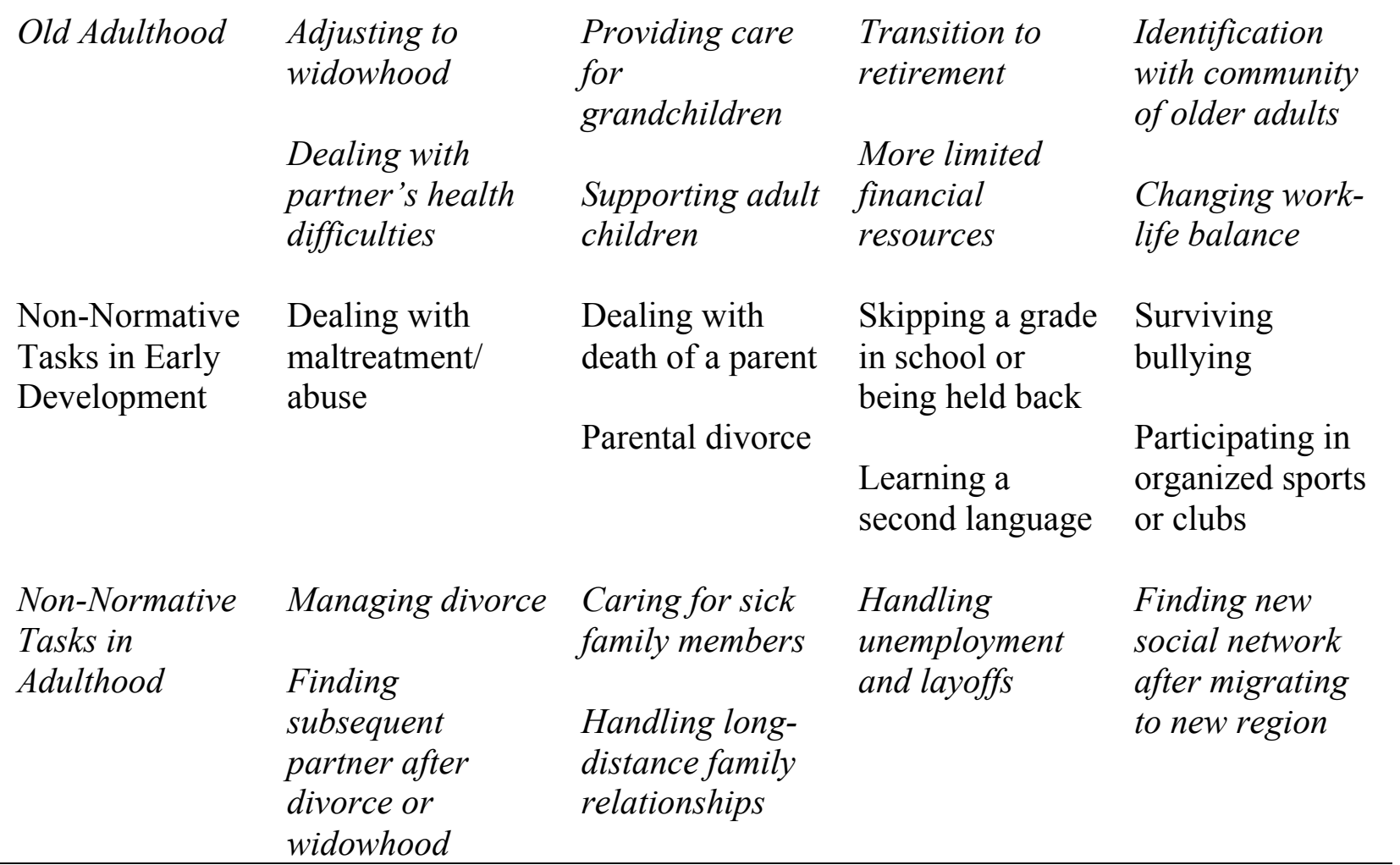

Note. Table extends Hutteman et al.'s (2014) Table 1 (p. 269) about developmental tasks in adulthood. Italicized rows draw strongly from Hutteman et al.'s work, and non-italicized rows represent new contributions. 